\title{
POROSTY ROSNĄCE WZDŁUŻ SZOSY WĄGROWIEC - MARGONIN W WIELKOPOLSCE
}

\author{
ANDRZEJ BRZEG ${ }^{1}$, ARTUR GOLIS $^{2}$, HALINA RATYŃSKA ${ }^{3}$
}

\footnotetext{
${ }^{1}$ Uniwersytet im. Adama Mickiewicza w Poznaniu, Wydział Biologii, Zakład Ekologii Roślin i Ochrony Środowiska, ul. Uniwersytetu Poznańskiego 6, 61-614 Poznań, ORCID 0000-0002-6373-6846

${ }^{2}$ Zespół Parków Krajobrazowych Województwa Wielkopolskiego, ul. Kościuszki 95, 61-716 Poznań ${ }^{3}$ halrat@wp.pl
}

\begin{abstract}
The lichen biota occurring along road no. 190 from Margonin to Wągrowiec (about $20 \mathrm{~km}$ ) was studied in 2017. Lichens growing on tree trunks, concrete poles, fallen branches and in soil were spotted. Presence of 61 taxa was acknowledged, among them 18 under legal protection and/or threatened in Poland. Their list comprises Cladonia mitis, Collema auriforme, Evernia prunastri, Melanelia exasperatula, Opegrapha rufescens, Opegrapha varia, Parmelina tiliacea, Peltigera canina, Pertusaria coccodes, Phaeophyscia chloantha, Physcia aipolia, Physconia distorta, Pleurosticta acetabulum, Punctelia subrudecta, Ramalina farinacea, $R$. fraxinea, R. pollinaria and Xanthoparmelia verruculifera.
\end{abstract}

Keywords: lichens, old trees, concrete poles, xerothermic sward, road, Poland

\section{WSTĘP}

Podczas inwentaryzacji i waloryzacji przyrodniczej przeprowadzonej w pasie drogi wojewódzkiej 190 na odcinku Margonin (od skrzyżowania drogi z ul. Ogrodową)-Wągrowiec (do ronda na skrzyżowaniu ul. Kościuszki i ul. Reja), w związku z planami jej przebudowy (Rozbudowa..., 2017), stwierdzono m.in. występowanie kilkudziesięciu gatunków porostów. Większość z nich porastała korę drzew przydrożnych, głównie starych jesionów i lip, inne znaleziono na betonowych słupach, kilka dalszych także na ziemi w płacie przydrożnej murawy kserotermicznej.

Ponieważ na zestawionej liście znalazły się interesujące gatunki prawnie chronione oraz uważane za rzadkie i zagrożone w Polsce, a także dlatego, że w ostatnim dwudziestoleciu nie było zbyt wielu publikowanych doniesień o porostach Wielkopolski (Kepel 1996, 2002; Kubiak 1999, 2008; Kubiak, Sucharzewska 2004; Gruszka 2010; Zarabska 2008, 2010; Zarabska-Bożejewicz 2017), w szczególności o występujących wzdłuż ciągów komunikacyjnych, postanowiono opublikować uzyskane materiały. 


\section{TEREN BADAŃ}

Badany pas drogowy odcinka drogi wojewódzkiej 190 (klasa drogi G) liczy około $20 \mathrm{~km}$, a szerokość jej jezdni wynosi $2 \times 3,5 \mathrm{~m}$ (Słowik 2017). Jest to ciąg biegnący od północnych rubieży miasta Wągrowiec do południowego skraju miasta Margonin (ryc. 1). Wzdłuż drogi po stronie wschodniej od Margonina do wsi Próchnowo znajduje się chodnik o szerokości około 2,0 m. Na pozostałym odcinku nie występują chodniki, poza krótkimi fragmentami zlokalizowanymi na terenie zabudowanym we wsiach: Próchnowo, Oporzyn, Pawłowo Żońskie, Toniszewo, Kopaszyn i Kobylec.

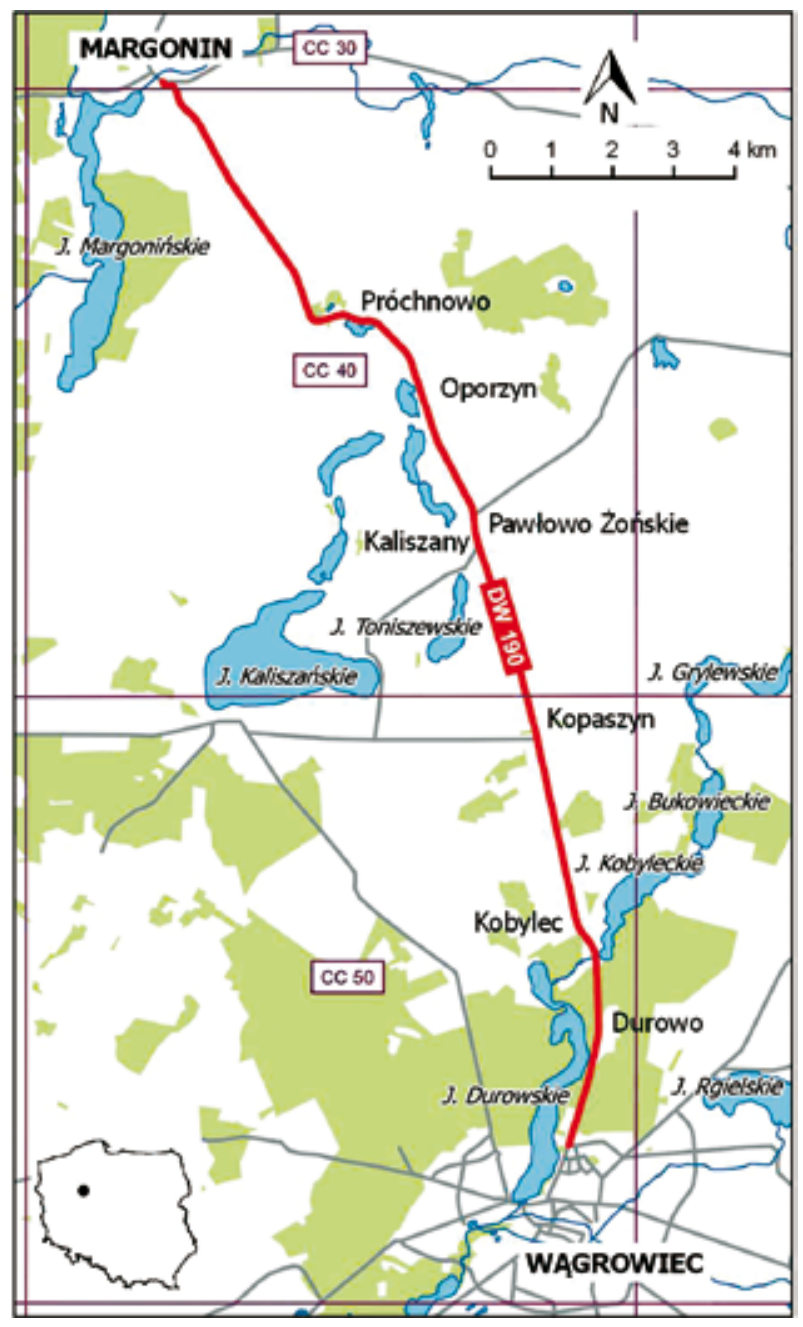

Ryc. 1. Mapka sytuacyjna terenu badań

Fig. 1. Situation map of the investigated area 
Miarą rozwoju ruchu kołowego jest wielkość wskaźnika motoryzacji, który określa liczbę samochodów osobowych przypadających na 1000 mieszkańców. Dla Polski wynosi on 485, dla Wielkopolski 564, a dla Wągrowca jest szczególnie wysoki - ponad 1000 (dane dla 2013 r., Plan..., 2016).

Średnie dobowe natężenie ruchu samochodowego na drodze 190 wynosi 4980 i jest największe w okolicach Wągrowca (Plan..., 2016), co odpowiada kategorii ruchu KR3 (Słowik 2017). Większość pojazdów stanowią samochody osobowe $-78,1 \%$.

Obecnie nawierzchnia drogi jest asfaltowa. Na większości przebiegu otaczają ją płytkie rowy i szpalery zadrzewień. Towarzysząca jej dendroflora jest bardzo bogata, liczy 100 taksonów (Ratyńska, Golis 2017). Są tam zarówno spontanicznie wyrosłe rodzime gatunki drzew i krzewów, jak również efekty dawnych nasadzeń roślin miejscowych i obcego pochodzenia w lasach czy na terenach zurbanizowanych oraz wzdłuż dróg. Taksony te utrzymują swoje stanowiska, a miejscami się rozprzestrzeniają. Bardzo dobrze zachowała się aleja lipowa pod Wągrowcem. Na dalszych odcinkach zadrzewienia przydrożne, poza lipą, tworzą m.in. topole, jesiony, klony oraz kasztanowce.

W trakcie rozpoznań lichenologicznych zwrócono uwagę na szczególnie okazałe drzewa. Największe lipy drobnolistne w alei przydrożnej w rejonie Wągrowca mają w pierśnicy blisko $300 \mathrm{~cm}$ obwodu. Najstarszym drzewem przydrożnym jest lipa drobnolistna rosnąca około 1,7 km od Margonina, po zachodniej stronie szosy. Wiek tego drzewa, o obwodzie w pierśnicy $375 \mathrm{~cm}$ i wysokości około $24 \mathrm{~m}$, szacuje się na około 150 lat (por. Larsen i Kristoffersen 2002). Najgrubszym i prawdopodobnie najstarszym drzewem w pobliżu badanej drogi jest jesion wyniosły o obwodzie $645 \mathrm{~cm}$ - pomnik przyrody rosnący w parku w Próchnowie. Jednak najczęściej średnie obwody w pierśnicy drzew przydrożnych oscylowały w granicach $80-180 \mathrm{~cm}$.

Badana droga przecina wiele miejscowości, gdzie w jej pobliżu zlokalizowano ogródki przydomowe i sady. Głównie jednak przebiega w krajobrazie rolniczym. Jest otoczona gruntami ornymi, na których uprawia się zboża i rzepak, rzadziej nieużytkami oraz odłogami, a także terenami podmokłymi, wykorzystywanymi ekstensywnie jako łąki, a niekiedy zarastającymi ziołoroślami. Wśród pól liczne są punktowe i liniowe, różnogatunkowe zadrzewienia oraz zakrzewienia. Obszary leśne znajdują się głównie w okolicy Wągrowca. Są tam przede wszystkim lasy liściaste (zdegenerowane grądy). Lokalnym obniżeniom i dolinom cieków towarzyszą łęgi. Na niewielkich powierzchniach stwierdzono leśne zbiorowiska zastępcze, głównie z sosną zwyczajną lub robinią. W bezpośrednim otoczeniu pasa drogowego spotyka się zanikające fragmenty muraw kserotermicznych Sileno otitae-Festucetum trachyphyllae (Ratyńska, Golis 2017).

Pod względem administracyjnym teren, przez który przebiega badany odcinek drogi, zlokalizowany jest w województwie wielkopolskim, w powiatach chodzieskim i wągrowieckim. 
Zgodnie z podziałem fizycznogeograficznym według Kondrackiego (2002) analizowany odcinek drogi jest położony w obrębie prowincji Niżu Środkowoeuropejskiego, podprowincji Niziny Środkowopolskiej i makroregionu Pojezierza Wielkopolskiego. Rozpatrując mikroregiony, to okolice Margonina leżą na Pojezierzu Chodzieskim (315.53), a Wągrowca na Pojezierzu Gnieźnieńskim (315.54). Badany teren charakteryzuje się rzeźbą młodoglacjalną, związaną z poznańską fazą zlodowacenia bałtyckiego. Ma to odzwierciedlenie w urozmaiconym ukształtowaniu powierzchni, w obecności licznych jezior i cieków wodnych.

Charakteryzowany odcinek drogi jest położony w VIII - środkowej dzielnicy rolniczo-klimatycznej (Gumiński 1948). Średnia roczna temperatura powietrza wynosi tam $8,0^{\circ} \mathrm{C}$, średnia stycznia około $-1,5^{\circ} \mathrm{C}$, a lipca $18,5^{\circ} \mathrm{C}$. Dni z przymrozkami występuje około $100-110$, a czas zalegania pokrywy śnieżnej waha się od 40 dni do 60 dni.

Opady są zazwyczaj niskie; ich średnia suma kształtuje się w zakresie 500$550 \mathrm{~mm}$ w ciągu roku (Atlas klimatyczny Polski 1973).

Wiatry wieją głównie z kierunku zachodniego i południowo-zachodniego. Najbardziej wietrznym okresem jest zima. Niezbyt często odnotowuje się wiatry bardzo silne.

Na mikroklimat mają wpływ liczne jeziora leżące w sąsiedztwie szlaku komunikacyjnego: J. Durowskie, J. Kobyleckie, J. Toniczewskie, J. Pawłowskie, J. Żońskie, J. Oporzyńskie, J. Próchnowskie, niewielkie rzeki: Rudka i Struga Gołaniecka, drobne oczka wodne, sieć rowów odwadniających oraz lokalne, podmokłe niecki terenu. Niestety stan wód nie jest dobry. Przykładowo, z oceny JCWP jezior Durowskiego i Kobyleckiego wynika zły stan wód przy umiarkowanym stanie ekologicznym (WIOŚ..., 2018).

Potencjalną roślinność naturalną Wielkopolski przedstawili Wojterski i in. (1982), a następnie Matuszkiewicz (2008). Na badanym terenie jest ona zróżnicowana i obejmuje cztery typy zbiorowisk leśnych oraz jeden nieleśny - wody i ich obrzeża $z$ roślinnością hydro- $i$ helofitów. Zdecydowanie przeważają siedliska liściastego lasu mieszanego - grądu Galio sylvatici-Carpinetum w postaci uboższej i żyznej. $\mathrm{Z}$ obniżeniami terenu i dolinami cieków związane są biotopy wilgotnych lasów liściastych: łęgu jesionowo-olszowego Fraxino-Alnetum i łęgu wiązowo-jesionowego Querco-Ulmetum minoris w podzespole przystrumykowym Q.-U. m. chrysosplenietosum. Tylko punktowo pojawiają się uboższe i suchsze siedliska kwaśnej dąbrowy Calamagrostio arundinaceae-Quercetum petraeae, związane z najsłabszymi glebami piaszczystymi.

Według geobotanicznego podziału Polski (Szafer 1972) powyższy teren obejmuje Krainę Wielkopolsko-Kujawską z Okręgiem Poznańsko-Gnieźnieńskim. W nowszym ujęciu Matuszkiewicza (1993) charakteryzowana droga przecina Podprowincję Środkowoeuropejską Właściwą, Dział Brandenbursko-Wielkopolski, Krainę Środkowowielkopolską, Okręg Poznański, podokręg 
Gośliński (B.1.6.j) oraz Okręg Pojezierza Gnieźnieńskiego, podokręg Wągrowiecki (B.2.1.a).

Na kartogramie siatki ATPOL (Zając A., Zając M. 2001) badany odcinek drogi DW 190 jest położony w obrębie następujących kwadratów: CC30, CC40 i CC50.

\section{MATERIAŁ I METODY}

Inwentaryzację bioty porostów epifitycznych, epiksylicznych i epilitycznych interesującego nas pasa drogowego przeprowadzono przede wszystkim w listopadzie 2017 r. W miesiącach wcześniejszych zbierano głównie porosty naziemne związane $z$ murawami. Łatwiejsze do identyfikacji gatunki notowano bezpośrednio w terenie, próbki trudniejszych zebrano do oznaczenia w warunkach laboratoryjnych.

Prace terenowe prowadzono metodą marszrutową, skupiając się na losowo wybranych punktach pasa drogowego. Począwszy od przedmieść Wągrowca punkty takie wypadały w odległości około $500-1000 \mathrm{~m}$. W każdym z nich notowano bądź zbierano porosty z 4-6 drzew po obydwu stronach drogi, z betonowych słupów, $z$ opadłych gałęzi bądź rosnące na ziemi. Lokalizację większości punktów, w których stwierdzono obecność szczególnie interesujących taksonów porostów, rejestrowano za pomocą odbiornika GPS Garmin Oregon 600. Łącznie zbadano lichenobiotę w ponad 30 takich punktach, czyli na około 300 drzewach, do wysokości przynajmniej $3 \mathrm{~m}$ od powierzchni gleby. Na podstawie liczby notowań przedstawiono lokalną skalę rozpowszechnienia rozpoznanych dotychczas gatunków: +++- pospolite i częste (ponad 10 notowań), ++- rozproszone (3-10 notowań), +- bardzo rzadkie i rzadkie (1-2 notowania).

Nazewnictwo znalezionych i oznaczonych taksonów porostów podano zasadniczo według Fałtynowicza (2003). Oznaczeń dokonano na podstawie kluczy Tobolewskiego (1972) oraz Nowaka i Tobolewskiego (1975), a także ikonografii zamieszczonej m.in. w opracowaniu Wójciak (2010) i w galeriach internetowych. Nie posługiwano się metodami chromatograficznymi dotyczącymi metabolitów wtórnych, dlatego niektóre taksony podano w ujęciu tradycyjnym jako agregaty.

Status gatunków prawnie chronionych przyjęto za Rozporządzeniem Ministra... (2014), a kategorie zagrożenia w Polsce za czerwoną listą Cieślińskiego $\mathrm{i}$ in. (2003), stosując następujące oznaczenia w nawiasach kwadratowych: OŚ ochrona ścisła; OC - ochrona częściowa; CR - krytycznie zagrożone; EN - wymierające; VU - narażone; NT - bliskie zagrożenia.

Gatunki drzew i inne substraty, na których występowały porosty, przedstawiono za pomocą następujących skrótów: bs - betonowe słupy (concrete poles), gj - głóg jednoszyjkowy Crataegus monogyna, jbs - jarząb szwedzki Sorbus 
intermedia, js - jesion wyniosły Fraxinus excelsior, jw - klon jawor Acer pseudoplatanus, lp - lipa drobnolistna Tilia cordata, og - opadłe gałęzie (fallen branches), pg - piaszczysto-gliniasta gleba w murawie kserotermicznej (sandy-loamy soil in a xerothermic sward), so - sosna zwyczajna Pinus sylvestris, śn śnieguliczka Symphoricarpos albus, tp - topole (głównie Populus balsamifera s.l.), wb - wierzby płaczące Salix $s p$.

W załączonym wykazie charakterystyka poszczególnych taksonów zawiera kolejno: nazwę łacińską (ewentualnie z często spotykanymi w literaturze synonimami), nazwę polską, status ochronny i/lub kategorię zagrożenia, lokalny stopień rozpowszechnienia i oznaczenie substratu.

\section{WYNIKI}

Na badanym terenie stwierdzono dotychczas występowanie 61 taksonów porostów należących do 14 rodzin. Większość rosła na przydrożnych drzewach.

Spośród wykazanych porostów 17 podlega ochronie prawnej (Rozporządzenie..., 2014) i/lub jest umieszczonych na polskiej czerwonej liście taksonów zagrożonych (Cieśliński i in. 2003). Wśród nich 5 taksonów objętych jest ochroną ścisłą (Melanelia exasperatula, Parmelina tiliacea, Punctelia subrudecta, Ramalina fraxinea, Xanthoparmelia verruculifera) i 5 częściową (Cladonia mitis, Peltigera canina, Pleurosticta acetabulum, Ramalina farinacea, $R$. pollinaria). Jeden takson-Melanelia exasperatula należy do kategorii krytycznie zagrożonych w kraju (CR), 3 do wymierających (EN: Physconia distorta, Pleurosticta acetabulum i Ramalina fraxinea), 7 do narażonych (VU: Opegrapha rufescens, Parmelina tiliacea, Peltigera canina, Phaeophyscia chloantha, Punctelia subrudecta, Ramalina farinacea i $R$. pollinaria), a 5 do bliskich zagrożenia (NT: Collema auriforme, Evernia prunastri, Opegrapha varia, Pertusaria coccodes oraz Physcia aipolia).

Zdecydowana większość chronionych i/lub zagrożonych gatunków (15) rosła na pniach starych przydrożnych jesionów oraz lip, przede wszystkim tam, gdzie drzewa takie tworzyły dłuższe szpalery, głównie w części drogi bliższej Margonina. Trzy gatunki były obecne ponadto w płacie przydrożnej murawy kserotermicznej. Nie stwierdzono rzadszych lub interesujących taksonów na betonowych słupach wzdłuż drogi.

\section{Systematyczny wykaz stwierdzonych taksonów}

\section{Opegraphaceae}

Opegrapha rufescens Pers. - pismaczek rudy: [VU]; ++; tp.

Opegrapha varia Pers. $[=$ O. lichenoides Pers. $]$ - pismaczek zmienny: $[\mathrm{NT}]$; ++; jbs, jw, tp. 


\section{Collemataceae}

Collema auriforme (With.) Coppins \& Laundon [=C. auriculatum Hoffm.] galaretnica uszata: [NT]; +; pg.

\section{Peltigeraceae}

Peltigera canina (L.) Willd. - pawężnica psia: [OC, VU]; +; pg.

Peltigera didactyla (With.) Laundon [=P. spuria (Ach.) DC.] - pawężnica drobna: +; pg.

\section{Lecideaceae}

Hypocoenomyce scalaris (Ach.) Choisy [=Lecidea scalaris (Ach.) Ach.] - paznokietnik ostrygowaty: +++ ; js, lp, tp.

Lecidella elaeochroma (Ach.) Choisy [=Lecidea olivacea (Hoffm.) Mass.] amylka oliwkowa: +; lp.

Placynthiella uliginosa (Schrader) Coppins \& P. James [=Lecidea uliginosa (Schrad.) Ach.] - ziarniak humusowy: +; pg.

Porpidia crustulata (Ach.) Hertel \& Knoph [=Lecidea crustulata (Ach.) Spreng.] - kamusznik właściwy: ++; bs.

Scoliciosporum chlorococcum (Graeve ex Stenham) Vězda [=Bacidia chlorococca (Graeve ex Stenham) Lettau] - szadziec ciemnozielony: ++; lp, js, og, tp.

Trapeliopsis flexuosa (Fr.) Coppins \& P. James [=Lecidea flexuosa (Fr.) Nyl.] szarek pogięty: +++; js, jw, lp, tp.

\section{Cladoniaceae}

Cladonia chlorophaea (Flk.) Spreng. agg. - chrobotek kieliszkowy: +; pg.

Cladonia furcata (Huds.) Schrader - chrobotek widlasty: +; pg.

Cladonia mitis (Sandst.) Hustich $[=C$. arbuscula ssp. mitis (Sandst.) Ruoss] chrobotek łagodny (=Ch. leśny p.p.): [OC]; +; pg.

Cladonia ochrochlora Flk. - chrobotek rdzawy: +; lp.

Cladonia rangiformis Hoffm. - chrobotek kolczasty: +; pg.

Cladonia subulata (L.) Weber in Wigg. agg. [=C. cornutoradiata (Coem.) Copf] - chrobotek rogoksztaltny: +; pg.

\section{Pertusariaceae}

Pertusaria albescens (Huds.) Choisy \& Werner in Werner [=P. discoidea (Pers.) Malme, P. globulifera (Turn.) Massal] - otwornica krążkowata: +++; js, jw, lp, tp.

Pertusaria coccodes (Ach.) Nyl. - otwornica szkarłatna: [NT]; ++; js, jw, lp. Phlyctis argena (Ach.) Flotow - rozsypek srebrzysty: +++; js, jw, lp, tp. 


\section{Lecanoraceae}

Lecanora albescens (Hoffm.) Flk. - misecznica biaława: ++; bs.

Lecanora allophana (Ach.) Nyl. - misecznica pogięta: +; js.

Lecanora argentata (Ach.) Malme [=L. subfuscata H.Magn.] - misecznica kasztanowata: +; js.

Lecanora chlarotera Nyl. - misecznica jaśniejsza: ++; js, lp, tp.

Lecanora conizaeoides Nyl. in Crombie - misecznica proszkowata; +++; jbs, js, jw, lp, og.

Lecanora dispersa (Pers.) Semmerf. - misecznica pospolita: ++; bs.

Lecanora pulicaris (Pers.) Ach. - misecznica brązowa: ++; lp, tp.

\section{Candelariaceae}

Candelaria concolor (Dickson) B. Stein - świetlinka pospolita: ++; js, jw, lp.

Candelariella aurella (Hoffm.) A. Zahlbr. - liszajecznik złocisty: ++; bs.

Candelariella vitellina (Ehrh.) Müll. Arg. - liszajecznik żółty: ++; js, jw, lp, tp.

Candelariella xanthostigma (Ach.) Lettau - liszajecznik ziarnisty: ++; js, lp, so, tp.

\section{Parmeliaceae}

Hypogymnia physodes (L.) Nyl. [=Parmelia physodes (L.) Ach.] - pustułka pęcherzykowata: ++; og, so, tp.

Melanelia exasperatula (Nyl.) Essl. [=Parmelia exasperatula $\mathrm{Nyl}$.$] - przylepka$ łuszczkowata: [OŚ, CR]; +; jbs.

Melanelia fuliginosa (Wib.) Fr. ex Duby [=Parmelia fuliginosa (Wib.) Nyl.] przylepka okopcona: +; lp.

Parmelia saxatilis (L.) Ach. - tarczownica skalna: +; lp.

Parmelia sulcata Taylor - tarczownica bruzdkowana: +++; jbs, js, jw, lp, og, tp, wb.

Parmelina tiliacea (Hoffm.) Hale [=Parmelia scortea Ach.] - szarzynka skórzasta: [OŚ, VU]; ++; js, lp.

Pleurosticta acetabulum (Neck.) Elix \& Lumsch [=Parmelia acetabulum (Neck.) Duby] - wabnica kielichowa: [OC, EN]; ++; js, lp.

Punctelia subrudecta (Nyl.) Krog [=Parmelia dubia (Wulf.) Schaerer] - biedronecznik zmienny: [OŚ, VU]; ++; jbs, og, tp; (ryc. 2).

Xanthoparmelia verruculifera (Nyl.) O. Blanco et al. [=Parmelia verruculifera Nyl.] - żełuczka ciemna: [OŚ]; +; jbs.

\section{Usneaceae}

Evernia prunastri (L.) Ach. - mąkla tarniowa: [NT]; +++; js, jw, lp.

Ramalina farinacea (L.) Ach. - odnożyca mączysta: [OC, VU]; ++; js, lp; (ryc. 3). 


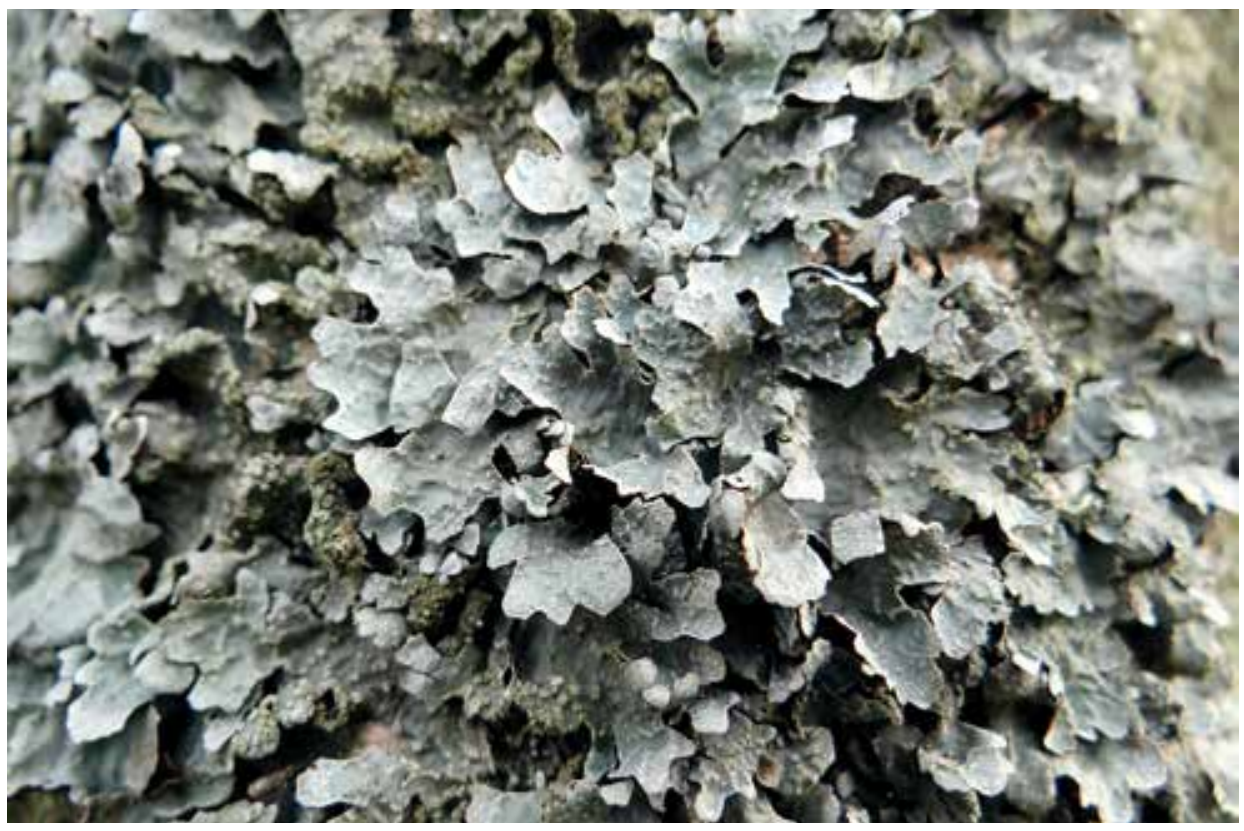

Ryc. 2. Plecha Punctelia subrudecta. Fot. H. Ratyńska

Fig. 2. Thallus of Punctelia subrudecta. Phot. H. Ratyńska

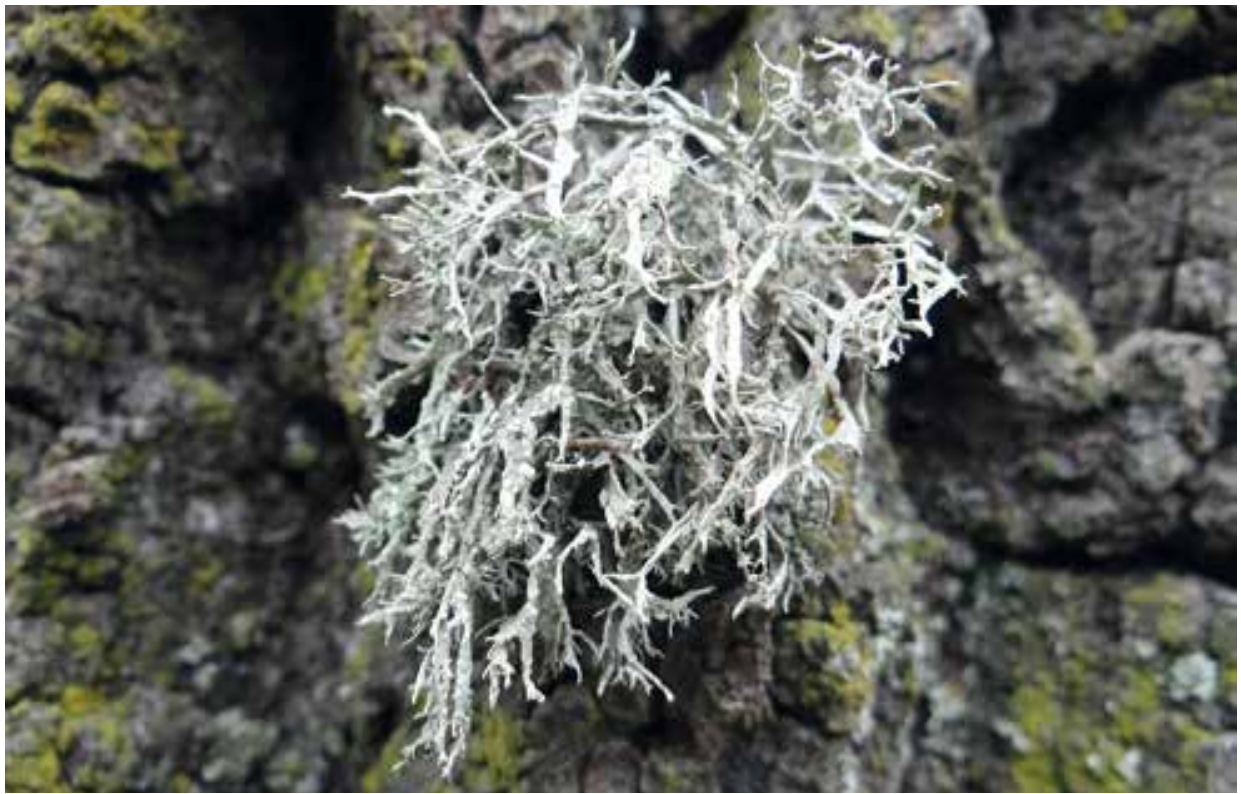

Ryc. 3. Plecha Ramalina farinacea. Fot. H. Ratyńska

Fig. 3. Thallus of Ramalina farinacea. Phot. H. Ratyńska 
Ramalina fraxinea (L.) Ach. - odnożyca jesionowa: [OŚ, EN]; ++; js; (ryc. 4). Ramalina pollinaria (Westr.) Ach. - odnożyca opylona: [OC, VU]; +; js, tp.

\section{Caloplacaceae}

Caloplaca citrina (Hoffm.) Th. Fr. - jaskrawiec cytrynowy: ++; bs, tp.

Caloplaca decipiens (Arnold) Blomb \& Forss. - jaskrawiec zwodniczy: ++; bs. Caloplaca holocarpa (Hoffm.) Waede [ $=$ C. pyracea (Ach.) Th. Fr. $]-$ jaskrawiec gruszowy: + ; jbs, tp.

Caloplaca saxicola (Hoffm.) Nordin [=C. murorum (Ach.) Th. Fr.] - jaskrawiec murowy: +; bs.

\section{Teloschistaceae}

Xanthoria parietina (L.) Th. Fr. - złotorost ścienny: +++; bs, gj, jbs, js, jw, lp, og, śn, tp, wb.

Xanthoria polycarpa (Hoffm.) Rieber - złotorost wieloowocnikowy: ++; gj, jbs, jw, og, śn.

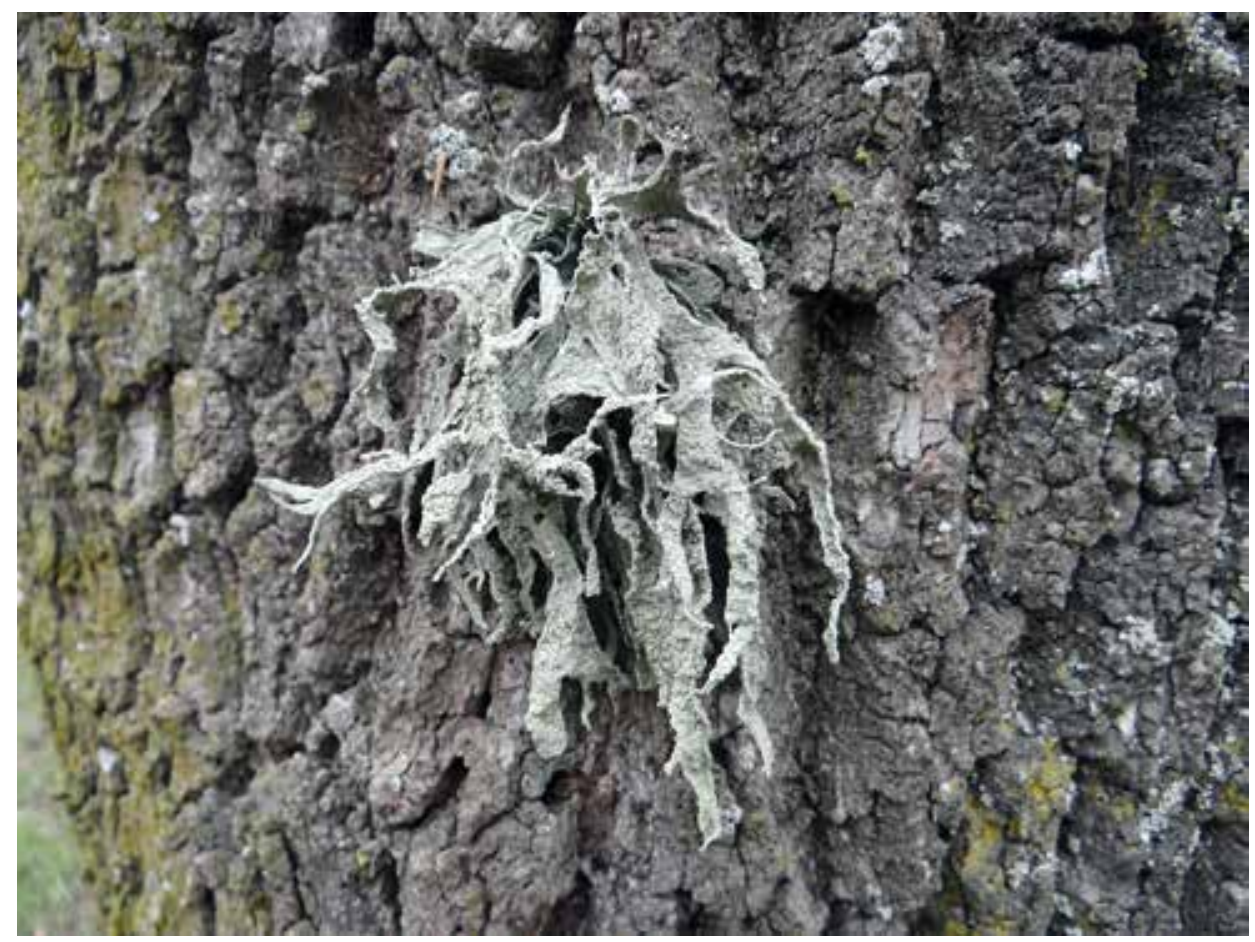

Ryc. 4. Plecha Ramalina fraxinea. Fot. H. Ratyńska

Fig. 4. Thallus of Ramalina fraxinea. Phot. H. Ratyńska 


\section{Physciaceae}

Phaeophyscia chloantha (Ach.) Moberg [=Physcia luganensis Mereschk.] - orzast luganeński: [VU]; +; jw, lp.

Phaeophyscia nigricans (Flk.) Moberg [=Physcia nigricans (Flk.) Stiz.] - orzast czarniawy: +++; bs, js, jw, og, lp, tp, wb.

Phaeophyscia orbicularis (Necker) Moberg [=Physcia orbicularis (Necker) Du Rietz] - orzast kolisty: +++; bs, jbs, js, jw, og, lp, tp, wb.

Physcia adscendens (Fr.) Olivier - obrost wzniesiony: +++; gj, jbs, js, jw, lp, og, tp, wb.

Physcia aipolia (Ehrh.) Hampe - obrost sinawy: [NT]; +; og, tp.

Physcia caesia (Hoffm.) Fürnrohr - obrost modry: ++; js, tp.

Physcia dubia (Hoff.) Lettau - obrost zmienny: +++; js, jw, lp, tp, wb.

Physcia tenella (Scop.) DC. in Lam. \& DC. - obrost drobny: +++; bs, jbs, js, jw, lp, og, tp, wb.

Physconia distorta (With.) Laundon [=Physcia pulverulenta (Schreb.) Hampe] - soreniec opylony: [EN]; +; lp.

Physconia grisea (Lam.) Poelt. [=Physcia grisea (Lam.) Lettau] - soreniec popielaty: ++; js, lp, tp; (ryc. 5).

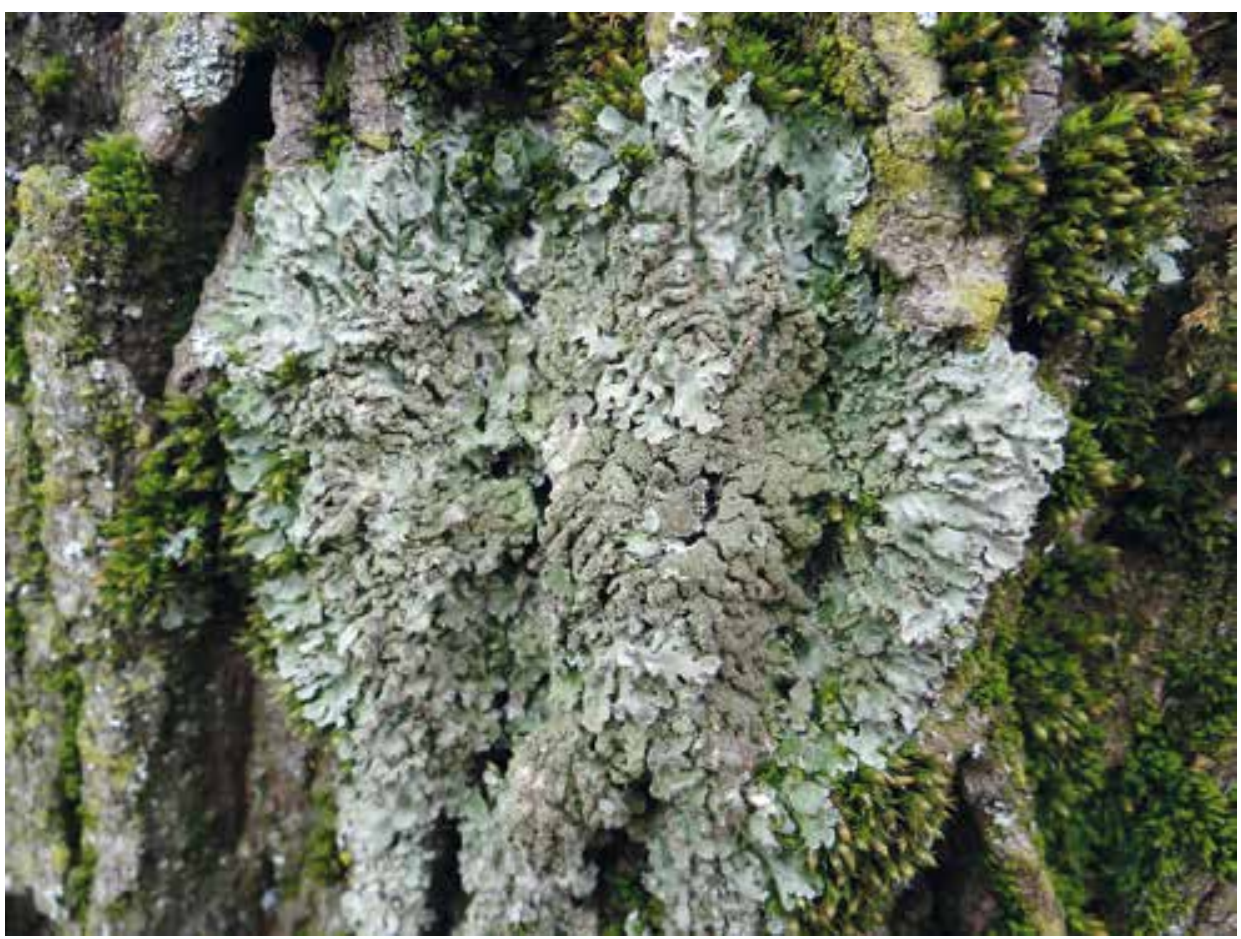

Ryc. 5. Plecha Physconia grisea. Fot. H. Ratyńska

Fig. 5. Thallus of Physconia grisea. Phot. H. Ratyńska 


\section{Leprariaceae}

Lepraria incana (L.) Ach. agg. - liszajec zwyczajny: +++; js, jw, lp, tp.

\section{PODSUMOWANIE I DYSKUSJA}

Badany odcinek drogi wojewódzkiej 190 Margonin-Wągrowiec przebiega przez zróżnicowany krajobraz rolniczy, leśny oraz zurbanizowany (oprócz części miasta Wągrowiec przecina wiele mniejszych miejscowości). Szlakowi komunikacyjnemu towarzyszą różnowiekowe i różnogatunkowe zadrzewienia. Na tym obszarze wykazano występowanie 61 gatunków porostów, w tym 18 prawnie chronionych i/lub zagrożonych w Polsce, z których na szczególną uwagę, w skali regionu Wielkopolski, zasługują: Collema auriforme, Melanelia exasperatula, Parmelina tiliacea, Physconia distorta, Pleurosticta acetabulum, Ramalina fraxinea, R. pollinaria i Xanthoparmelia verruculifera. Warto podkreślić, że ich plechy są na ogół dobrze wykształcone. Najwięcej stanowisk jest skupionych na starych drzewach rosnących bliżej Margonina. Do naziemnych należą m.in. taksony z rodzajów Cladonia i Peltigera. Obserwowano ponadto porosty na słupach i słupkach przydrożnych, będących antropogenicznymi odpowiednikami siedlisk naskalnych. Zwraca uwagę fakt, że w obrębie wiekowej alei lipowej na przedmieściach Wągrowca biota porostów była bardzo uboga; odnotowano tam jedynie najpospolitsze gatunki (m.in.: Hypocoenomyce scalaris, Lepraria incana, Phaeophyscia orbicularis, Trapeliopsis flexuosa i Xanthoria parietina). Może to mieć związek $\mathrm{z}$ większym skażeniem powietrza w bezpośrednim sąsiedztwie miasta (por. Kiszka 1990; Kepel 2002; Wójciak 2007).

Ponieważ brak aktualnej literatury dotyczącej porostów przydrożnych (np. Rydzak 1970), uzyskane materiały można odnieść do bogactwa bioty porostów terenów parkowych. Przykładowo, Kubiak i Sucharzewska (2004) z parku w Gogolewie wymienili 26 gatunków, a z drzew przydrożnych zaledwie 14, Kubiak i Nowakowska (2016) z parku w Łężanach podali 87 gatunków, a Brzeg (2019) w otoczeniu Kanału Bydgoskiego stwierdził 48 taksonów. Lichenobiota obrzeży badanej drogi, choć stosunkowo uboga, pod względem ilościowym jest więc porównywalna z obszarami parkowymi. Warto jednak podkreślić, że odznacza się relatywnie dużym jeszcze udziałem gatunków chronionych i zagrożonych, dla których stare drzewa przydrożne mogą stanowić ważne ostoje w obrębie przeważnie otwartego krajobrazu rolniczego. W tym kontekście istotna wydaje się uwaga, że lichenobiota badanych przydroży jest bogatsza niż zlokalizowanego w sąsiedztwie, większego powierzchniowo rezerwatu przyrody „Dębina” koło Wągrowca, gdzie aktualnie odnaleziono 53 gatunki (Gruszka 2010).

Omawiana grupa organizmów wzdłuż drogi Margonin-Wągrowiec jest w znaczącym stopniu zagrożona przede wszystkim wycinką drzew, związaną 
z planowaną przebudową drogi wojewódzkiej nr 190. Ich występowaniu nie sprzyjają również narastające zanieczyszczenia, w tym komunikacyjne, a także przynajmniej okresowe susze związane z ocieplaniem się klimatu.

\section{LITERATURA}

Atlas klimatyczny Polski (1973): IMGW, Wyd. Geol. Warszawa.

Brzeg A. (2019): Porosty (Lichenes). [W:] Ratyńska H. (red.). Przyroda parku nad Starym Kanałem Bydgoskim: 141-150. Wyd. Uniw. K. Wielkiego. Bydgoszcz.

Cieśliński S., Czyżewska K., Fabiszewski J. (2003): Czerwona lista porostów wymarłych i zagrożonych w Polsce. - Red list of exting and threatened lichens in Poland. Monogr. Bot., 91: $1-37$.

Fałtynowicz W. (2003): The lichens, lichenicolous and allied fungi of Poland. An annotated checklist. Ss. 435. W. Szafer Inst. of Bot., Polish Acad. of Sci. Kraków.

Gruszka W. (2010): Zmiany bioty porostów rezerwatu „Dębina” koło Wągrowca. Bad. Fizjogr., Ser. B, R. I(B59): 173-183.

Gumiński R. (1948): Próba wydzielenia dzielnic rolniczo-klimatycznych w Polsce. Przegl. Meteor.-Hydrol., I, 1.

Kepel A. (1996): Porosty (Lichenes) rezerwatu „Meteoryt Morasko”. Roczn. Nauk. Pol. Tow. Ochr. Przyr. „Salamandra”, 1: 47-56.

Kepel A. (2002): Niedostrzegane porosty. Wśród zwierząt i roślin. Kronika Miasta Poznania, 2002-2003: 81-90.

Kiszka J. (1990): Lichenoindykacja obszaru województwa krakowskiego. Stud. Ośr. Dokum. Fizjogr., 18: 201-212.

Kondracki J. (2002): Geografia fizyczna Polski. Ss. 441. Wyd. Nauk. PWN. Warszawa.

Kubiak D. (1999): Porosty rezerwatu „Dębno” koło Rawicza (S Wielkopolska). Bad. Fizjogr. nad Polską Zach., B, 48: 233-237.

Kubiak D. (2008): Nowe stanowiska rzadkich i interesujących porostów w południowej Wielkopolsce. Bad. Fizjogr. nad Polską Zach., B, 57: 99-108.

Kubiak D., Nowakowska P. (2016): Porosty epifityczne parku przypałacowego w Łężanach (NE Polska) - Epiphytic lichens of the manor park in Łężany (NE Poland). Act. Botan. Silesiaca, 16: 101-114.

Kubiak D., Sucharzewska E. (2004): Porosty parku wiejskiego w Gogolewie (południowa Wielkopolska). Bad. Fizjogr. nad Polską Zach., B, 53: 147-151.

Larsen F. K., Kristoffersen P. (2002): Tilia's physical dimensions over time. Journ. of Arboriculture, 28(5): 209-214.

Matuszkiewicz J. M. (1993): Krajobrazy roślinne i regiony geobotaniczne Polski. Ss. 110. PAN, Inst. Geogr. i Przestrz. Zagosp., Pr. Geogr., 158. Wrocław, Warszawa, Kraków.

Matuszkiewicz J. M. (2008): Potencjalna roślinność naturalna Polski. PAN, Inst. Geogr. i Przestrz. Zagosp. Warszawa.

Nowak J., Tobolewski Z. (1975): Porosty polskie. Opisy i klucze do oznaczania porostów w Polsce dotychczas stwierdzonych lub prawdopodobnych. Ss. 1177. PWN. Warszawa-Kraków.

Plan zrównoważonego rozwoju publicznego transportu zbiorowego dla miasta Wągrowiec na lata 2016-2026.

Ratyńska H., Golis A. (2017): Inwentaryzacja przyrodnicza. [W:] Przebudowa drogi wojewódzkiej nr 190 na odcinku od m. Margonin do m. Wągrowiec. Poznań [mskr.].

Rozbudowa drogi wojewódzkiej nr 190 na odcinku od Miasta Margonin do Miasta Wągrowiec, 2017. 
Rozporządzenie Ministra Środowiska z dnia 9 października 2014 r. w sprawie ochrony gatunkowej grzybów. Dz.U. RP, poz. 1408.

Rydzak J. (1970): Flora i ekologia porostów drzew przydrożnych. Ann. UMCS, Sec. C, Biol., 25: $149-157$.

Słowik A. (2017): Projekt koncepcyjny rozbudowy DW190 na odcinku od m. Margonin do m. Wągrowiec wraz z uzyskaniem decyzji środowiskowej. Inwestor: Wielkopolski Zarząd Dróg Wojewódzkich w Poznaniu ul. Wilczak 51 61-623 Poznań [mskr.].

Szafer W. (1972): Szata roślinna Polski Niżowej. [W:] Szafer W., Zarzycki K. (red.). Szata roślinna Polski, I: 17-188. PWN. Warszawa.

Tobolewski Z. (1972): Porosty. Klucz do oznaczania pospolitszych gatunków krajowych. Wyd. 2. Ss. $252+$ fot. PWN. Warszawa.

WIOŚ w Poznaniu (2018): Ocena stanu jednolitych części wód jeziornych w województwie wielkopolskim za rok 2017.

Wojterski T., Wojterska H., Wojterska M. (1982): Mapa potencjalnej roślinności naturalnej środkowej Wielkopolski. Bad. Fizjogr. nad Polską Zach., B, 32: 7-35 + mapa.

Wójciak H. (2007): Porosty, mszaki, paprotniki. Ser. Flora Polski, wyd. 2 uzup. i popr. Ss. 368. Multico Ofic. Wyd. Warszawa.

Zarabska D. (2008): Chronione i zagrożone gatunki porostów epifitycznych fitocenoz leśnych okolic Nowego Tomyśla. Chrońmy Przyr. Ojcz., 64(3): 92-108.

Zarabska D. (2010): Interesujące gatunki porostów Równiny Nowotomyskiej i ich występowanie na Nizinie Wielkopolsko-Kujawskiej. Bad. Fizjogr., Ser. B, R. I(B59): 153-172.

Zarabska-Bożejewicz D. (2017): Nowe stanowisko Diploschistes muscorum (Scop.) R. Sant. na Nizinie Wielkopolsko-Kujawskiej. Bad. Fizjogr., R. VII(B65): 129-135.

Zając A., Zając M. (2001): Atlas rozmieszczenia roślin naczyniowych w Polsce. - Distribution atlas of vascular plants in Poland. Nakł. Pr. Chorologii Komputerowej Inst. Botan. UJ. Ss. 716. Kraków.

\section{LICHENS GROWING ALONG THE ROAD BETWEEN WĄGROWIECAND MARGONIN (WIELKOPOLSKA REGION)}

\section{Summary}

The subject of the investigation was the lichen biota along road No 190 from Margonin to Wagrowiec (about $20 \mathrm{~km}$ ). The field studies were conducted on 30 randomly chosen sites, situated 500-1.000 m apart from each other. In each of them the lichens were collected from 4-6 trees on either side of the road, and from other habitats: concrete poles, fallen branches and the soil.

Presence of 61 taxa was stated, among them 18 under legal protection and/or endangered in Poland. They include Cladonia mitis, Collema auriforme, Evernia prunastri, Melanelia exasperatula, Opegrapha rufescens, O. varia, Parmelina tiliacea, Peltigera canina, Pertusaria coccodes, Phaeophyscia chloantha, Physcia aipolia, Physconia distorta, Pleurosticta acetabulum, Punctelia subrudecta, Ramalina farinacea, $R$. fraxinea, $R$. pollinaria and Xanthoparmelia verruculifera. The above mentioned species, the most valuable from the point of view of nature protection, tended to concentrate around Margonin. On a old lime 
alley close to Wagrowiec the lichen biota was poor, and only the most common taxa (Hypocoenomyce scalaris, Lepraria incana, Phaeophyscia orbicularis, Trapeliopsis flexuosa and Xanthoria parietina) were identified there. It may be related to higher air pollution in the vicinity of the town of Wagrowiec.

Notably, old trees, even when growing along quite busy roads, may still host protected and endangered lichens in the prevailing open, agricultural landscape of Wielkopolska. 